\title{
Technical Efficiency of Maize Production in Fluoride Affected Locales, Tamil Nadu: A Stochastic Frontier Approach
}

\author{
Naveen Kumar, P.* and P. Paramasivam \\ Department of Agricultural Economics, TNAU, Coimbatore, Tamil Nadu, India
}

*Corresponding author: naveen191992@gmail.com (ORCID ID: 0000-0003-3839-1329)

Received: 02-04-2019

Revised: 07-07-2019

Accepted: 22-08-2019

\begin{abstract}
To estimate the technical efficiency of maize production among fluoride affected and non affected locales of Tamil Nadu. A multi-stage sampling method involving a combination of purposive and random sampling procedures was employed in drawing up the samples for collecting primary data. The sample size is about 120. Stochastic frontier production function is used to estimate technical efficiency of maize. The result of stochastic frontier production function indicated that FYM, Potassium, machine power, irrigation and management index have significant influence on yield of maize in less fluoride affected locale, while, seed rate, nitrogen, phosphorous, machine power and irrigation are significantly influence the yield of maize in moderately fluoride affected locale, in case of highly fluoride affected locale, seed rate, nitrogen, phosphorous, potassium and irrigation are significantly influencing the yield of maize, while, nitrogen, potassium, irrigation and management index are significantly influences the yield of maize in non affected locale. The study suggests that awareness of fluoride contamination and averting measures must be disseminated to the farmers.
\end{abstract}

\section{Highlights}

( In Management index, Occupation and Land holding are positively correlated with crop yield in the study area.

(0) The study concluded that highly fluoride affected farmers are technically less efficient than non affected farmers, less and moderately affected farmers.

Keywords: fluoride affected locale, Maize and technical efficiency

Groundwater is a prime source for human intake, agricultural and industrial uses in several regions around the globe (Kouras et al. 2007; Jalali and Ranjbar 2010). Because of inadequacy of surface water, groundwater contributes more to the necessity of human actions. The demand for quality water for irrigation of crops is ever increasing, whereas the availability of water remains comparatively constant in most parts of the world. Continuous depletion of groundwater increases global threats, including a sudden decline in agriculture (AeschbachHertig and Gleeson 2012; Turner et al. 2019). This leads to contamination in groundwater such as fluoride discharge in water. Fluoride is one of the critical ions that influence groundwater quality.
Anthropogenic interventions such as overuse of phosphatic fertilizers in a farmers field, brick manufacturing industries, over deepening of well are the lead sources for the release of fluoride in ground water as well as the environment and it is becoming worldwide problem (Pickering 1985; Ozvath 2009). India annually extracts around 251 cubic kilometre which is 52 per cent of the total global annual extraction of groundwater compared with China and United states of America who extracts just $112 \mathrm{cu} . \mathrm{km}$ combined together. India is the largest user of groundwater and ninety per cent of groundwater is used for irrigation that covers 60 per cent of the total irrigated area (World press, 2017). Over abstraction of groundwater and over use 
AESRA

of phosphatic fertilizer, pesticides in agriculture is the cause of fluoride contamination in groundwater (Ramesh and Soorya 2012; Ali et al. 2016; Mukherjee et al. 2018). In India, many states are affected with endemic fluorosis viz., Andhra Pradesh, Tamil Nadu, Karnataka, Gujarat, Rajasthan, Punjab, Haryana, Bihar and Kerala (CGWB, 2016). High concentration of fluoride is often above $1.5 \mathrm{mg} / \mathrm{l}$, results in severe problems (Ramesh and Soorya 2012). Tamil Nadu is one among them, 23 out of 33 districts were affected by fluoride contaminated water. Salem, Erode, Dharmapuri, Coimbatore, Thiruchirapalli, Dindugal, Theni, Perambalur, Vellore, Madurai, Virudhunagar and Krishnagiri are subjected to fluoride contamination and the effects are with dental and skeletal fluorosis (CGWB, 2016). Maize is one of the cereal crop cultivated in India and Tamil Nadu. Maize is known as queen of cereals as it has highest yield potential. In India, maize is the third most important food crops after rice and wheat. It contributes about 10 per cent of total food grain production (APEDA 2015). In india, 15 million farmers are engaged in maize cultivation (FICCI 2018). The area under maize cultivation has increased at a CAGR of 2.5 per cent from 7.5 million hectare in 2004-05 to 9.4 million hectare in 2013-14, the further increase in production is due to increase in yield (Thomas et al. 2018). Farmers were continued to extract the groundwater for maize irrigation and this led to contamination of fluoride in groundwater in study area. Though there are several empirical studies on agriculture related to water pollution, there are only few studies dealt with problems in the agricultural sector caused by fluoride contamination in ground water. With this context, the present study has assessed the technical efficiency of maize production among fluoride affected and non affected locales of Tamil Nadu.

\section{MATERIALS AND METHODS}

\section{Data Collection and Sampling}

Multistage random sampling method was used for the selection of study area. At first stage, District wise fluoride affected locales of Tamil Nadu with the permissible limit of above $1.5 \mathrm{mg} / \mathrm{L}$ were collected from central ground water board, 2014-15. In second stage, districts are segregated into different agro climatic zones based on fluoride content and finally, western zone was selected. At third stage, it was classified into affected locale (highly, moderately and less fluoride affected locale) and non affected locale. From this two blocks from each of the locales, then three villages of each block were selected based on secondary data (Appendix-I). Finally, 120 samples was selected based on sample size methodology given by Yamane (1967).

$$
\text { Yamane Formula }=(n)=\frac{N}{1+N\left(e^{2}\right)}
$$

Where: $n=$ sample size; $N=$ total number of farmers population (6021618); $e=$ error limit/ level of precision of $5 \%$ (0.05).

From the above sampling formula total required samples calculated is 399 , but by considering time constraint along with convenience about 30 per cent i.e. 120 samples were preferred for the study.

\section{Management Index used in Production Function}

Following (Makary and Rees 1981), the management index was derived for this study. The management function (log-linear form) employed is as follows,

$$
\ln (Y)=b_{0}+b_{1} \mathrm{EXP}+b_{2} \mathrm{EDU}+b_{3} \mathrm{OCC}+b_{4} \mathrm{LH}+e
$$

Where,

$$
Y=\text { Yield }(\text { Kg per hectare) }
$$

EXP $=$ Total farming experience in years

$E D U=$ Education Dummy $(=1$, if secondary school and above and ' 0 ' otherwise)

OCC $=$ Occupation Dummy $(=1$, if agriculture as the primary occupation and ' 0 ' otherwise)

$$
\begin{aligned}
& L H=\text { Land holding in ha. } \\
& e=\text { error term }
\end{aligned}
$$

Using the estimated coefficients of the function and the respective mean value of EXP, EDU, OCC and $\mathrm{LH}$, the management index was worked out for all respondents, employing the following equation.

$$
M I_{i}=\frac{\left(b_{1} E X P_{i}+b_{2} E D U_{i}+b_{3} O C C_{i}+b_{4} L H_{i}\right)}{b_{1} \overline{E X P}+b_{2} \overline{E D U}+b_{3} \overline{O C C}+b_{4} \overline{L H}}
$$

Where,

$M_{I} i=$ Management index of the sample farms

$b_{1}, b_{2}, b_{3}$ and $b_{4}=$ the estimated coefficients of management function 
$E X P_{i^{\prime}} E D U_{i^{\prime}} O C C_{i}$ and $L H_{i}=$ the variables used in the $\mathrm{i}^{\text {th }}$ farm

$E X P, E D U, O C C$ and $L H=$ the mean value of the sample farm

Further, the estimated management index was incorporated in the production functions.

\section{Technical Efficiency}

In order to study the technical efficiency, stochastic frontier production function was specified as given below.

\section{The Stochastic Frontier}

Stochastic frontier was first proposed by (Aigner et al. 1977; Meeusen and Van den Broeck 1977) to estimate technical efficiency of producers using parametric econometric approach. The stochastic frontier production is specified for cross sectional data with an disturbance/error term which has two components such as random effect and technical inefficiency (Coelli 1994).

The general form of stochastic frontier approach,

$$
\begin{aligned}
& Y_{i}=\left(X_{i k} \beta\right) e^{E i} \\
& Y_{i}=X_{i k} \beta+V_{i}-U_{i} \\
& i=1,2, \ldots . . n ; k=1,2, \ldots \ldots k
\end{aligned}
$$

Where,

$Y_{i}$ is the dependent variable of the $i^{\text {th }}$ farm, $X_{i}$ is a vector of $K \times 1$ inputs of the $i^{\text {th }}$ farm, $\beta$ is an $(K \times 1)$ vector of unknown parameters and $E_{i}$ a farm specific disturbance term. The error term/ disturbance term includes random effects $\left(V_{i}\right)$ are assumed to be independently distributed as $N(0$, $\left.\sigma^{2} U\right)$. Technical inefficiency $\left(U_{i}\right)$ being a non-negative random variables $\left(U_{i} 0\right)$ and often assumed to be independently identically distributed.

The model specification form,

$$
\begin{aligned}
& \sigma^{2}=\sigma_{u}^{2}+\sigma_{v}^{2} \\
& \gamma^{2}=\frac{\sigma_{u}^{2}}{\sigma_{u}^{2}+\sigma_{v}^{2}}
\end{aligned}
$$

$\sigma_{u}{ }^{2}=$ variance parameter that denotes deviation due to inefficiency

$\sigma_{v}{ }^{2}=$ variance parameter that denotes deviation due to statistical noise

$\sigma^{2}=$ variance parameter that denotes that total deviation from the frontier $\gamma=$ parameter range between 0 and 1

If gamma $\gamma=0$, difference between yield obtained by the farmers and efficient yield is due to statistical noise.

If $\gamma=1$, difference is purely due to inefficient use of technology

In this paper, parameters are analysed using maximum likelihood estimates with single step approach by following (Battese and Coelli 1995). For the present study, Cobb-Douglas production frontier using cross sectional data with half-normal distribution (Kaur et al. 2010; Shantha et al. 2012; Dhehibi et al. 2014; Singh et al. 2016) is employed.

The general form is,

$$
\begin{aligned}
& \quad \operatorname{Ln} Y_{i}=\beta_{0}+\sum_{k=1}^{n} \beta_{j} \operatorname{Ln}\left(X_{i k}\right)+\left(V_{i}-U_{i}\right) \\
& \begin{aligned}
\operatorname{Ln}(Y)=\beta_{0}+\beta_{1} \ln \left(X_{1}\right)+\beta_{2} \ln \left(X_{2}\right)+\beta_{3} \ln \left(X_{3}\right)+\beta_{4} \ln \left(X_{4}\right) \\
\quad+\beta_{5} \ln \left(X_{5}\right)+\beta_{6} \ln \left(X_{6}\right)+\beta_{7} \ln \left(X_{7}\right)+\beta_{8} \ln \left(X_{8}\right)+ \\
\quad \beta_{9} \ln \left(X_{9}\right)+V_{i}-U_{i}
\end{aligned} \\
& \begin{aligned}
\operatorname{Ln}(\text { Yield })=\beta_{0}+{ }_{1} \beta \ln (\text { Seed } \mathrm{qty})+\beta_{2} \ln (\mathrm{FYM})+\beta_{3} \\
\quad \ln (\mathrm{N})+\beta_{4} \ln (\mathrm{P})+\beta_{5} \ln (\mathrm{K})+\beta_{6} \ln (\mathrm{HL})+\beta_{7}
\end{aligned} \\
& \quad \ln (\mathrm{MP})+\beta_{8} \ln \text { (Irrigation) }+\beta_{9} \ln (\mathrm{MI})+V_{i}-U_{i} \\
& \mathrm{Y}=\text { Yield in number of kg per ha. } \\
& \beta_{1}-\beta_{9}=\text { Parameters to be estimated or production } \\
& \text { elasticities } \\
& X_{1}=\text { Total number of planting material/ seed quantity } \\
& (\text { kg per ha.) } \\
& X_{2}=\text { Quantity of farm yard manure applied (tonnes } \\
& \text { per ha.) } \\
& X_{3}=\text { Quantity of total nitrogen applied (kg per ha.) } \\
& X_{4}=\text { Quantity of total phosphorus applied (kg per ha.) } \\
& X_{5}=\text { Quantity of total potassium applied (kg per ha.) } \\
& X_{6}=\text { Human labour (man days per ha.) } \\
& X_{7}=\text { Machine power (hrs per ha.) } \\
& X_{8}=\text { Irrigation (m }{ }^{3} \text { per ha.) } \\
& X_{9}=\text { Management Index }
\end{aligned}
$$

The farm specific technical efficiencies $\left(T E_{i}\right)$ are computed by taking the exponentiation of the negative of $u_{i^{\prime}}$ as per (Coelli 1995, Nasim Ahmad et al. 2018).

$$
T E=\frac{y_{i}}{\exp \left(x_{i} \beta\right)}=\frac{\exp \left(x_{i} \beta-u_{i}\right)}{\exp \left(x_{i} \beta\right)}=\exp \left(-u_{i}\right)
$$

The Stata software was used to estimate the parameters of the stochastic production frontier and technical inefficiency effect simultaneously. 


\section{RESULTS AND DISCUSSION}

\section{Management Index}

Management index was derived by dependent variable crop yield $(Y)$ on independent variables such as farming experience, education, occupation and land holding. The estimated coefficients for the fluoride affected and non affected locales are presented in Table 1. Only two out of sixteen coefficients are non-significant. Farming experience is had positive correlation with crop yield expect for non affected locale. Head of household education had positive correlation with crop yield expect for highly fluoride affected locale. Occupation and Land holding are positively correlated with crop yield in the study area.

\section{Technical Efficiency in Maize Production of Fluoride affected and Non affected Locale of Tamil Nadu}

The stochastic parameter estimates obtained with regard to Maize crop in less fluoride affected locale are presented in Table 2.

The estimated lamda $(\lambda)$ parameter is 2.598, which indicates that the total variance is mainly due to inefficiency, whereas random errors are less important. The percentage of total variance due to variation in efficiency is 87.096 per cent. The estimated variance for the variation in efficiency ( sigma $^{2} u$ value) is equal to 0.108 which is considerably larger than the variation due to random errors of $0016\left(\operatorname{sigma}^{2} v\right.$ value).

Table 1: Estimated Parameters of Management Index for Fluoride Affected Locales and Non Fluoride Affected Locale

\begin{tabular}{ccccc}
\hline Parameter & Less affected & Moderately affected & Highly affected & Non affected \\
\hline EXP & $0.14^{* * *}(4.72)$ & $0.43^{* *}(2.98)$ & $0.23^{*}(1.94)$ & $0.45(0.06)$ \\
EDU & $0.07^{* * *}(3.85)$ & $0.04^{* *}(2.67)$ & $0.13(0.42)$ & $0.11^{* *}(2.73)$ \\
OCC & $0.52^{* * *}(3.26)$ & $0.21^{* *}(2.86)$ & $0.17^{* * *}(3.81)$ & $0.39^{* * *}(4.12)$ \\
LH & $0.47^{* *}(2.84)$ & $0.13^{* *}(2.24)$ & $0.36^{* * *}(4.33)$ & $0.53^{* * *}(3.97)$ \\
Constant & $7.33(1.48)$ & $9.15^{* *}(2.43)$ & $3.21(0.55)$ & $5.29^{* *}(2.34)$ \\
$\mathrm{R}^{2}$ & 0.74 & 0.68 & 0.81 & 0.79 \\
\hline
\end{tabular}

Note: ***-Significant at $1 \%$ level; ** - Significant at $5 \%$ level; * - Significant at $10 \%$ level; figures in parenthesis indicates t-value.

Table 2: Maximum Likelihood Estimates for Maize production in Fluoride affected and Non affected Locale of Tamil Nadu

\begin{tabular}{|c|c|c|c|c|c|c|c|c|c|}
\hline \multirow{3}{*}{$\begin{array}{r}\text { S1. } \\
\text { No. }\end{array}$} & \multirow{3}{*}{ Parameter } & \multicolumn{8}{|c|}{ Farm categories } \\
\hline & & \multicolumn{2}{|c|}{ Less affected } & \multicolumn{2}{|c|}{ Moderately affected } & \multicolumn{2}{|c|}{ Highly affected } & \multicolumn{2}{|c|}{ Non affected } \\
\hline & & Parameter & Std.err & Parameter & Std.err & Parameter & Std.err & Parameter & Std.ern \\
\hline & Intercept & 0.871 & 17.842 & $2.042^{* * *}$ & 0.350 & 8.618 & 41.813 & 0.390 & 21.024 \\
\hline 1 & Seed rate & -0.675 & 0.498 & $1.369^{* * *}$ & 0.686 & $0.615^{* *}$ & 0.238 & -2.317 & 0.510 \\
\hline 2 & FYM (tons / ha) & $0.371^{* *}$ & 0.167 & 0.753 & 0.769 & 0.440 & 0.371 & -0.109 & 0.803 \\
\hline 3 & $\mathrm{~N}(\mathrm{~kg} / \mathrm{ha})$ & 0.036 & 0.047 & $-0.215^{* * *}$ & 0.081 & $0.108^{* *}$ & 0.055 & $0.141^{*}$ & 0.072 \\
\hline 4 & $\mathrm{P}(\mathrm{kg} / \mathrm{ha})$ & 0.016 & 0.122 & $-0.308^{*}$ & 0.157 & $-0.126^{* *}$ & 0.057 & 0.353 & 0.310 \\
\hline 5 & $\mathrm{~K}$ (kg / ha) & $0.205^{* *}$ & 0.094 & 0.219 & 0.154 & $0.188^{* *}$ & 0.086 & $0.297^{* *}$ & 0.140 \\
\hline 6 & HL (man days / ha) & -0.011 & 0.076 & -0.134 & 0.112 & -0.004 & 0.052 & 0.098 & 0.062 \\
\hline 7 & MP (hrs/ ha) & $6.328^{* * *}$ & 2.221 & $0.160^{* * *}$ & 0.025 & 0.955 & 1.176 & $0.265^{* * *}$ & 0.020 \\
\hline 8 & Irrigation & $0.046^{* *}$ & 0.022 & $0.074^{* *}$ & 0.034 & $0.030^{* *}$ & 0.015 & $0.061^{*}$ & 0.024 \\
\hline \multirow[t]{7}{*}{9} & MI & $2.621^{* * *}$ & 0.652 & 0.737 & 0.716 & 0.184 & 0.316 & $2.028^{* * *}$ & 0.638 \\
\hline & Lambda & $2.598^{* *}$ & 1.152 & $2.397^{* *}$ & 0.671 & $2.357^{* * * *}$ & 1.133 & $4.033^{* *}$ & 1.074 \\
\hline & sigma $^{2}$ & 0.124 & & 0.027 & & 0.118 & & 0.190 & \\
\hline & $\operatorname{sigma}^{2} \mathrm{v}$ & 0.016 & & 0.004 & & 0.100 & & 0.011 & \\
\hline & $\operatorname{sigma}^{2} u$ & 0.108 & & 0.023 & & 0.018 & & 0.179 & \\
\hline & log likelihood & 79.737 & & 87.086 & & 70.541 & & 84.610 & \\
\hline & variation in efficiency & 87.096 & & 85.185 & & 84.745 & & 94.210 & \\
\hline
\end{tabular}

Note: ${ }^{* * *} ;{ }^{* *} ;{ }^{*}$ - Significant at $1 \%, 5 \%$ and $10 \%$ level. 
In less fluoride affected locale, it could be observed that the coefficient (production elasticity) of machine power and management index were found significant at one per cent level. The estimated production elasticity of machine power and management index were 6.328 and 2.621, respectively, which showed that every one per cent increase in machine power and management index would increase the per hectare yield of maize by 6.328 and 2.621per cent respectively. The coefficient of farm yard manure, potassium and irrigation were found significant at five per cent level. The production elasticity of farm yard manure, potassium and irrigation would increase the per hectare yield of maize by 0.371 per cent, 0.205 per cent and 0.046 per cent respectively.

The estimated lamda $(\lambda)$ parameter is 2.397, which shows that the total variance is mainly due to inefficiency, whereas random errors are less important. The percentage of total variance due to variation in efficiency is 85.185 per cent. The estimated variance for the variation in efficiency (sigma ${ }^{2} u$ value) is equal to 0.023 which is considerably larger than variation due to random errors $0.004\left(\right.$ sigma $^{2} \mathrm{v}$ value).

As regards moderately fluoride affected locale, the estimated coefficient of seed rate, nitrogen, machine power were found positive and significant at one per cent level. The estimated production elasticity of seed rate, nitrogen, machine power were 1.369, 0.215 and 0.160 respectively, which indicated that every one per cent increase in seed rate, nitrogen and machine power from the existing mean level would increase the per hectare yield of maize by 1.369 per cent, 0.215 per cent and 0.160 per cent. The coefficient of irrigation was found to be positive and significant at five per cent level. The production elasticity of irrigation would increase the yield by 0.074 per cent. The estimated coefficient of phosphorous was found to be statistically significant at ten per cent level. The production elasticity of phosphorous was negative. The coefficient of phosphorous was 0.308 , which indicated that for every one per cent increase in phosphorous would decrease the yield per hectare of maize by 0.308 per cent.

The estimated lamda $(\lambda)$ parameter is 2.357, which indicates that the total variance is mainly due to inefficiency, whereas random errors are less important. The percentage of total variance due to variation in efficiency is 84.754 per cent. The estimated variance for the variation in efficiency (sigma ${ }^{2} u$ value) is equal to 0.018 which is considerably larger than variation due to random errors of $0.100\left(\right.$ sigma $^{2} \mathrm{v}$ value).

Among highly fluoride affected locale, it could be inferred that the estimated coefficient of seed rate, nitrogen and potassium were positively significant at five per cent level. The estimated coefficient of the seed rate, nitrogen and potassium was $0.615,0.108$ and 0.188 , respectively, which indicated that every one per cent increase in seed rate, nitrogen and potassium would increase the per hectare yield of maize by $0.615,0.108$ and 0.188 per cent respectively. The estimated coefficient of phosphorous and irrigation were found to be statistically significant at one per cent level. The production elasticity of phosphorous and irrigation were negative. The coefficient of phosphorous and irrigation were 0.126 and 0.030, which indicated that for every one per cent increase in phosphorous and irrigation would decrease the yield per hectare of maize by 0.126 and 0.030 per cent respectively.

The estimated lamda $(\lambda)$ parameter is 4.033 , which shows that the total variance is mainly due to inefficiency, whereas random errors are less important. The percentage of total variance due to variation in efficiency is 94.210 per cent. The estimated variance for the variation in efficiency (sigma ${ }^{2} u$ value) is equal to 0.179 which is considerably larger than variation due to random errors of 0.011 (sigma $^{2} v$ value).

In the case of non affected locale, it could be observed that the coefficient (production elasticity) of machine power and management index was positively significant at one per cent level. The estimated coefficient of the machine power and management index was 0.265 and 2.028, respectively, which indicated that every one per cent increase in machine power and management index would increase the per hectare yield of maize by 0.265 and 2.028 per cent respectively. The coefficient of potassium was found to be statistically significant at 5 per cent level. The production elasticity potassium is 0.297 , which indicated that one per cent increase in the use of potassium would increase the yield per hectare of maize by 0.297 per cent. The coefficient of nitrogen and irrigation at ten per cent level. The production elasticity of nitrogen and irrigation 
were 0.141 and 0.061 respectively, which indicated that every one per cent increase in the quantity of nitrogen and irrigation used from the existing mean level would increase the maize yield by 0.141 and 0.061 per cent respectively.

\section{Technical Efficiency Distribution of Maize Farmers in Fluoride Affected and Non Affected Locale}

The technical efficiency distribution of maize farmers in fluoride affected and non affected locale is presented in Table 3 and shown in Fig. (1,2,3 and 4). The variation in the levels of efficiency of maize growers in less fluoride affected locale ranged from 61.00 to 99.99 with mean technical efficiency of 88.40 per cent. The mean level of technical efficiency indicated that on an average 11.60 per cent of the maize growers falling short of the maximum possible level of technology.

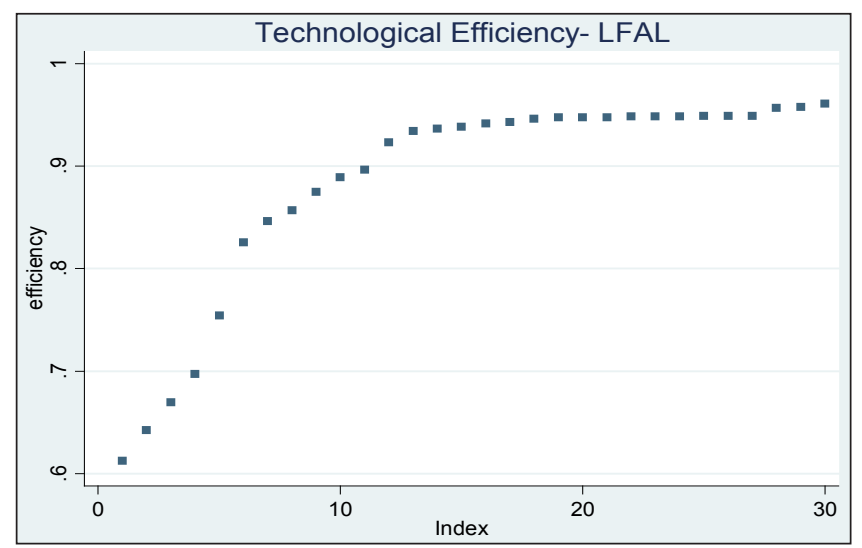

Fig. 1: Technical Efficiency Distribution of Maize Farmers in Less Fluoride Affected Locale (LFAL)

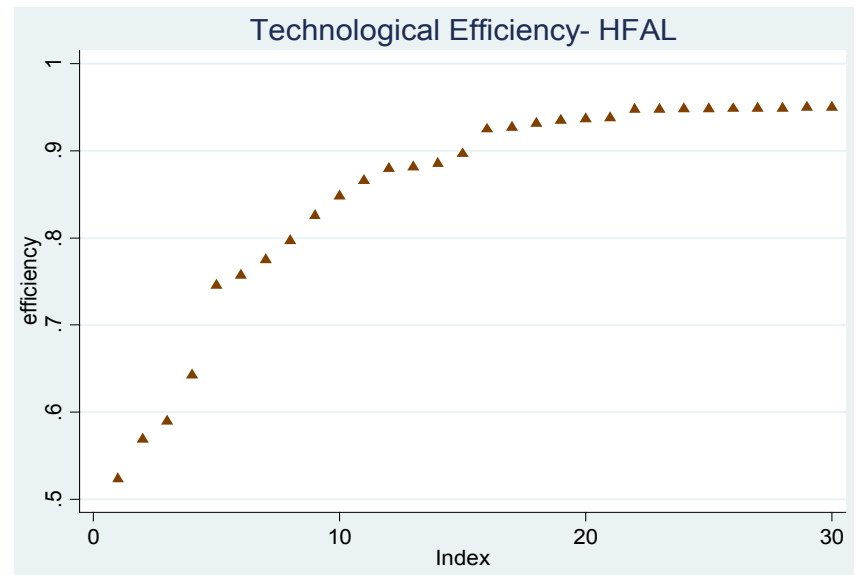

Fig. 3: Technical Efficiency Distribution of Maize Farmers in Highly Fluoride Affected Locale (HFAL)
Table 3: Technical Efficiency Distribution of Maize Farmers in Fluoride Affected and Non Affected Locale in Tamil Nadu

\begin{tabular}{ccccc}
\hline Frequency & $\begin{array}{c}\text { Less } \\
\text { affected } \\
\text { locale }\end{array}$ & $\begin{array}{c}\text { Moderately } \\
\text { affected } \\
\text { locale }\end{array}$ & $\begin{array}{c}\text { Highly } \\
\text { affected } \\
\text { locale }\end{array}$ & $\begin{array}{c}\text { Non } \\
\text { affected } \\
\text { locale }\end{array}$ \\
\hline$<50$ & $0(0.00)$ & $0(0.00)$ & $0(0.00)$ & $0(0.00)$ \\
$51-60$ & $0(0.00)$ & $1(3.33)$ & $3(10.00)$ & $0(0.00)$ \\
$61-70$ & $4(13.34)$ & $4(13.33)$ & $1(3.33)$ & $0(0.00)$ \\
$71-80$ & $1(3.33)$ & $3(10.00)$ & $4(13.33)$ & $4(13.33)$ \\
$81-90$ & $6(20.00)$ & $6(20.00)$ & $7(23.34)$ & $4(13.33)$ \\
$>91$ & $19(63.33)$ & $16(53.34)$ & $15(50.00)$ & $22(73.34)$ \\
\hline Total & $30(100.00)$ & $30(100.00)$ & $30(100.00)$ & $30(100.00)$ \\
MTE & 0.884 & 0.848 & 0.853 & 0.915 \\
\hline
\end{tabular}

Note: MTE: Mean Technical Efficiency.

Figures in the parenthesis represent percentage to the total

Therefore it is possible to increase the maize yield by 11.60 percent of maize growers on an average

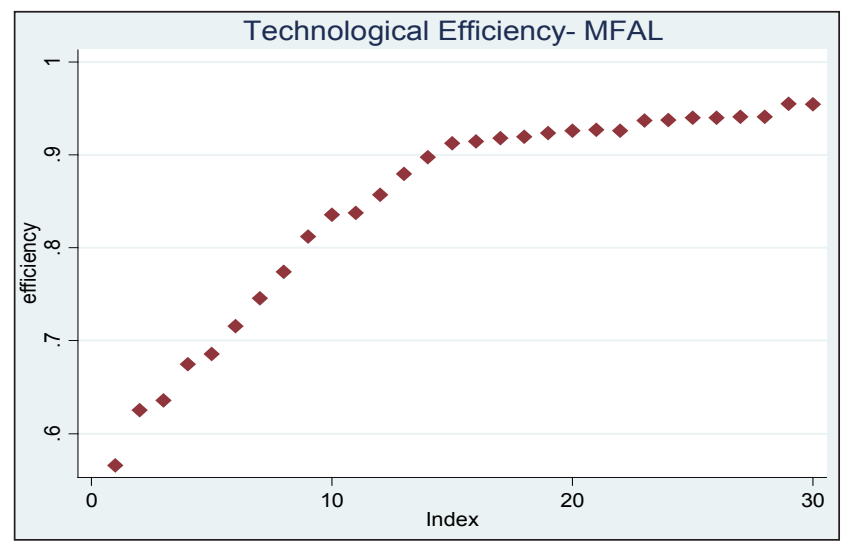

Fig. 2: Technical Efficiency Distribution of Maize Farmers in Moderately Fluoride Affected Locale (MFAL)

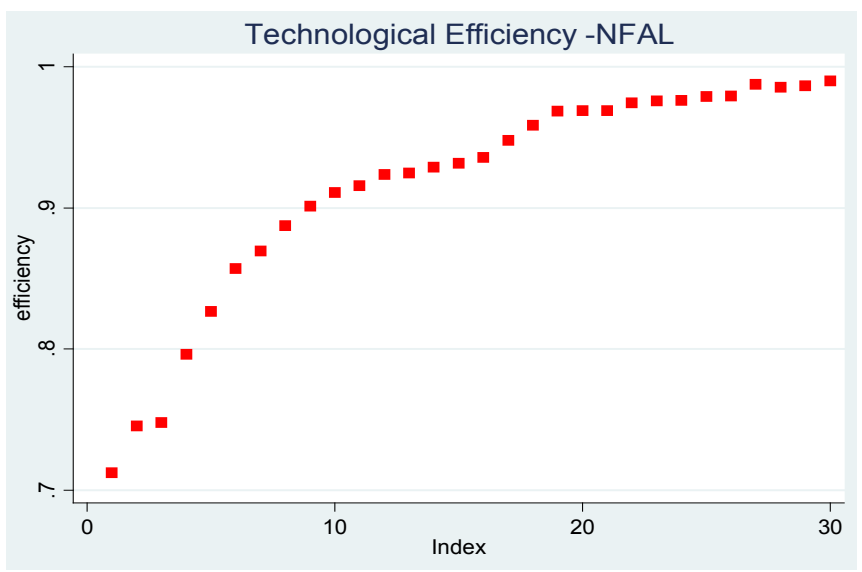

Fig. 4: Technical Efficiency Distribution of Maize Farmers in Non Fluoride Affected Locale (HFAL) 
by adopting the similar technology used by the best performers. 63.33 percent of the farmers belonged to the more efficient category (>91 per cent), 20.00 per cent belong to most efficient category (81-90 per cent) and 13.34 per cent of them belonged to the medium efficient category (61-70 per cent) and 3.33 percent of them belonged efficient category (71-80 per cent).

As regards moderately fluoride affected locales, it could be seen from the table that the efficiency of maize growers had a mean technical efficiency of about 84.80 per cent. It implies that the yield of maize can be increased to 15.20 per cent only by increasing the efficiency of these production systems with no additional inputs. Majority of farmers (53.34 per cent) achieved a technical efficiency above 90 per cent followed by 20.00 per cent of farmers falling in the technical efficiency range of $81-90$ per cent, 13.33 per cent of the farmers falls in the efficiency in the range of 61-70 per cent and remaining 10.00 per cent of the farmers were in the range of 71-80 per cent.

Among highly fluoride affected locale, the average technical efficiency estimated was 85.30 per cent indicating that output can be raised by 14.70 per cent by efficient crop management practices without having to increase the level of application of inputs. Out of 100 per cent, 50.00 per cent of farmers falls under the range of above 91.00 per cent. Nearly 23.34 per cent of farmers are seen under the range of 81-90 per cent followed by 13.33 per cent of farmers in the efficiency range of 71-80 per cent, 10.00 per cent of farmers falls in the efficiency range of 51-60 and the rest 3.33 per cent of the farmers were in the range of 61-70 per cent.

In the case of non affected locale, the efficiency of maize growers had a mean technical efficiency of about 91.50 per cent. It implies that the yield of maize can be increased to 8.50 per cent only by increasing the efficiency of the production systems with no additional inputs. Majority of farmers (73.34 per cent) achieved a technical efficiency above 90 per cent followed by 13.33 per cent of farmers falling in the technical efficiency range of both 81-90 per cent, and 71-80 per cent.

\section{CONCLUSION}

From the results of the study it is concluded that, FYM, Potassium, machine power, irrigation and management index were significantly influencing the yield of maize in less fluoride affected locale, while, seed rate, nitrogen, phosphorous, machine power and irrigation were significantly influencing the yield of maize in moderately fluoride affected locale. In case of highly fluoride affected locale, seed rate, nitrogen, phosphorous, potassium and irrigation are significantly influence the yield of maize, while, nitrogen, potassium, irrigation and management index were significant factors which influence the yield of maize in non affected locale. Moreover in moderately and highly fluoride affected locale maize farms may reduce the usage of phosphorous to get more yield, since the variable is negative. Hence, the study concluded that highly fluoride affected farmers are technically less efficient than non affected farmers, less and moderately affected farmers. The study suggests that awareness on fluoride contamination and averting measures must be disseminated to the farmers.

\section{ACKNOWLEDGEMENTS}

Authors express their gratitude to Indian Council of Social Science Research, New Delhi, India for providing Doctoral fellowship to carry out research to the first author. We would like to extend our thanks and appreciation to all the farmers who participated in the individual interview.

\section{REFERENCES}

Aeschbach-Hertig, W. and Gleeson, T. 2012. Regional strategies for the accelerating global problem of groundwater depletion. Nature Geoscience, 5(12): 853.

Agricultural and Processed Food Products Export Development Authority, 2015. http://apeda.gov.in/ apedawebsite/SubHead_Products/Maize.htm.

Aigner, D., Lvell, C. and Schmidt, P. 1977. Formulation and estimation of stochastic frontier production function models. Journal of Econometrics, 6(2): 21-37.

Ali, S., Thakur, S.K., Sarkar, A. and Shekhar, S. 2016. Worldwide contamination of water by fluoride. Environmental Chemistry Letters, 14: 291-315.

Battese, E. and Coelli, T. The Model for Technical Efficiency effect in a Stochastic Frontier Production Function for pannal data. Empirical Economics, 20: 325-332. 1995.

Central Groundwater Board. 2016. “Groundwater Scenario of India", 2015-16.

Coelli, T. 1994. A Guide to Frontier Version 4.1: A Computer Program for Stochastic Frontier Production and Cost Function Estimation. Australia: University of New England. 
Coelli, T. 1995. Recent Development in Frontier Modeling and efficiency Measurement. Australian Journal of Agricultural Economics, 39(3): 15-26.

Dhehibi, B., Aw-Hassan, A., Alimari, A. and Haddad, N. 2014. Technical Efficiency and Its Determinants in Food Crop Production: A Case Study of Farms in West Bank, Palestine, 16: 717-730.

FICCI. 2018. http://ficci.in/spdocument/22966/India-MaizeSummit.pdf.

Jalali, M. and Ranjbar, F. 2010. Aging effects on phosphorus transformation rate and fractionation in some calcareous soils. Geoderma, 155(1-2): 101-106.

Kaur, M., Mahal, A.K., Sekhon, M.K. and Kingra, H.S. 2010. Technical efficiency of wheat production in Punjab: A Regional Analysis. Agricultural economics research review, 23(347-2016-17029), 173.

Kouras, A., Katsoyiannis, I. and Voutsa, D. 2007. Distribution of arsenic in groundwater in the area of Chalkidiki, Northern Greece. Journal of Hazardous materials, 147(3): 890-899.

Makary, S.R. and Rees, H. 1981. An index of management efficiency for Egyptian agriculture: a case study of large farms. Journal of Agricultural Economics, 32(2): 189-196.

Meeusen, W. and van den Broeck, J. 1977. Efficiency estimation from Cobb-Douglas production functions with composed error. International economic Review, 18: 435-444.

Mukherjee, I. and Singh, U.K. 2018. Groundwater fluoride contamination, probable release, and containment mechanisms: a review on Indian context. Environmental geochemistry and health, 40(6): 2259-2301.

Nasim Ahmad, Sinha, D.K. and Singh, K.M. 2018. Productivity and Resource Use Efficiency in Wheat: A Stochastic Production Frontier Approach, Economic Affairs, 63(3): 611-616.
Ozsvath, D.L. 2009. Fluoride and environmental health: A review. Reviews in Environmental Science \& Biotechnology, 8: 59-79.

Pickering, W.F. 1985. The mobility of soluble fluoride in soils. Environmental Pollution (Series B), 9: 281-308.

Ramesh, K. and Soorya, V. 2012. Fluoride contamination in drinking water in palacode region, Tamil Nadu. Int. J. Res. Chem. Environ., 2: 116-123.

Shantha, A., Ali, B.G.H. and Bandara, R.A.G. 2012. Efficiency and managerial ability of paddy farming under minor irrigation conditions: a frontior production function approach. Journal of Agricultural Sciences-Sri Lanka, 7(3).

Singh, U., Singh, R.B. and Gautam, S.S. 2016. Comparison of Technical Efficiency of Soybean Farmers in Madhya Pradesh. International Journal of Agricultural and Statistical Sciences, 12(1): 223-228.

Thomas Felix, K., Murali Gopal, S., Ashok, K.R., Panneerselvam, S. and Duraisamy, M.R. 2018. Technical efficiency of maize production in different vulnerable agro-climatic zones of Tamil Nadu. Journal of Pharmacognosy and Phytochemistry, 7(4): 498-502.

Turner, S.W., Hejazi, M., Yonkofski, C., Kim, S.H. and Kyle, P. 2019. Influence of Groundwater Extraction Costs and Resource Depletion Limits on Simulated Global Non renewable Water Withdrawals Over the Twenty-First Century. Earth's Future, 7(2): 123-135.

World Press. 2017. https://socialissuesindia.wordpress. com/2017/12/27/alarming-fall-in-groundwater-levels-inindia/

Yamane, Taro. 1967. Statistics, An Introductory Analysis, 2nd Ed., New York: Harper and Row. 


\section{Appendix-I}

To fulfil the objective, area selected for the study was based on secondary data obtained from Ground water year book; Tamil Nadu (2014-15). Sample area was selected based on the following criteria.

1. District wise fluoride affected area of Tamil Nadu with the permissible limit of $1.5 \mathrm{mg} / \mathrm{L}$ is shown in Table 1.

\begin{tabular}{|c|c|c|c|}
\hline Sl. No. & District & Block & Fmg/L \\
\hline 1 & Coimbatore & 1. P.K. Palayam & 1.60 \\
\hline \multirow[t]{2}{*}{2} & Dharmapuri & 1. Nagadasampatt & 1.80 \\
\hline & & 2. Thoppur & 1.70 \\
\hline \multirow[t]{3}{*}{3} & Dindigul & 1. Thoppampatti & 1.97 \\
\hline & & 2. Natham & 1.78 \\
\hline & & 3. Dindigul & 1.65 \\
\hline \multirow[t]{3}{*}{4} & Erode & 1. Athani & 1.95 \\
\hline & & 2. Ammapet & 1.86 \\
\hline & & 3. Bangalapudur & 1.65 \\
\hline 5 & Namakkal & 1. Mohanpur & 1.59 \\
\hline 6 & Perambalur & 1. Kunnam & 1.76 \\
\hline \multirow[t]{2}{*}{7} & Pudukkottai & 1. Viralimalai & 1.65 \\
\hline & & 2. Rattumavadi & 1.54 \\
\hline 8 & Ramnad & 1. Bogalur & 1.72 \\
\hline \multirow[t]{3}{*}{9} & Salem & 1. Akkaraikadu & 1.80 \\
\hline & & 2. S.K. Garden & 1.70 \\
\hline & & 3. Idapadi & 1.60 \\
\hline \multirow[t]{2}{*}{10} & Sivagangai & 1. Manakudi & 1.64 \\
\hline & & 2. Chettinad & 1.55 \\
\hline 11 & Theni & 1. Andipatti & 1.56 \\
\hline \multirow[t]{2}{*}{12} & Tirunelveli & 1. Ambasamudram & 2.14 \\
\hline & & 2. Vasudevanallur & 1.56 \\
\hline \multirow[t]{2}{*}{13} & Tuticorin & 1. Kalungumalai & 1.65 \\
\hline & & 2. Kallurani & 1.54 \\
\hline 14 & Villupuram & 1. Villupuram & 1.55 \\
\hline 15 & Virudhunagar & 1. Tamilpadi & 1.58 \\
\hline
\end{tabular}

Source: Ground water year book, Tamil Nadu (2014-15)

2. Based on the above table (Table 1) the various district has been segregated into different agro climatic zone shown in Table 2 and further mean value for fluoride content for each zone was occupied finally zone with highest mean value i.e. western zone was selected.

\begin{tabular}{ccc}
\hline $\begin{array}{c}\text { Sl. } \\
\text { No. }\end{array}$ & Zone & F mg/L (Average) \\
\hline 1 & North Eastern Zone & 1.55 \\
2 & North Western Zone & 1.68 \\
3 & Western Zone & 1.71 \\
4 & Cauvery Delta Zone & 1.60 \\
5 & Southern Zone & 1.67 \\
\hline
\end{tabular}

3. From the Western Zone of Tamil Nadu, Fluoride Contaminated Ground Water blocks was selected and furnished in Table 3.

\begin{tabular}{|c|c|c|c|}
\hline S1. No. & District & Block & Fmg/L \\
\hline \multirow[t]{2}{*}{1} & Coimbature & 1. P.K.Palayam & 1.60 \\
\hline & & 1. Thoppampatti & 1.97 \\
\hline \multirow[t]{3}{*}{2} & Dindigul & 2. Natham & 1.78 \\
\hline & & 3. Dindigul & 1.65 \\
\hline & & 1. Athani & 1.95 \\
\hline \multirow[t]{2}{*}{3} & Erode & 2. Ammapet & 1.86 \\
\hline & & 3. Bangalapudur & 1.65 \\
\hline 4 & Perambalur & 1. Kunnam & 1.76 \\
\hline 5 & Theni & 1. Andipatti & 1.56 \\
\hline
\end{tabular}

4. Finally for clear picture of study area class interval for fluoride content was taken and blocks were classified into low, medium and high accordingly given in Table 4. Further From each classification two blocks was purposively selected.

\begin{tabular}{lll}
\hline Classification & Fluoride Affected Area & $\begin{array}{l}\text { Class } \\
\text { Interval }\end{array}$ \\
\hline Low & $\begin{array}{l}\text { (a) Andipatti, (b) P.K. Palayam, } \\
\text { (c) Dindigul, (d) Bangalapudur }\end{array}$ & $1.59-1.69$ \\
Moderate & (a) Kunnam, (b) Natham & $1.69-1.83$ \\
High & (a) Thoppampati, (b) Athani, & $1.83-1.97$ \\
& (c) Ammapet & \\
\hline
\end{tabular}


AESRA

5. List of selected villages and farmers is furnished in Table 5.

Table 5: Distribution of sample respondents in study area

\begin{tabular}{|c|c|c|c|c|c|}
\hline S1. No. & Locale & District & Block & Villages & $\begin{array}{l}\text { No. of Sample } \\
\text { Farmers }\end{array}$ \\
\hline \multirow{4}{*}{1} & \multirow{4}{*}{$\begin{array}{l}\text { Low Fluoride } \\
\text { Affected Locale }\end{array}$} & \multirow{2}{*}{ Coimbatore } & \multirow{2}{*}{ P.K. Palayam } & 1 & \multirow{2}{*}{15} \\
\hline & & & & 3 & \\
\hline & & \multirow{2}{*}{ Theni } & \multirow{2}{*}{ Andipatti } & 1 & \multirow{2}{*}{15} \\
\hline & & & & 3 & \\
\hline \multicolumn{4}{|l|}{ Sub Total (A) } & 6 & 30 \\
\hline \multirow{3}{*}{2} & \multirow{3}{*}{$\begin{array}{l}\text { Moderate Fluoride } \\
\text { Affected Locale }\end{array}$} & \multirow[b]{2}{*}{ Dindugal } & \multirow[b]{2}{*}{ Natham } & 1 & \multirow[b]{2}{*}{15} \\
\hline & & & & 2 & \\
\hline & & Perambalur & Kunam & 3 & 15 \\
\hline \multicolumn{4}{|l|}{ Sub Total (B) } & 6 & 30 \\
\hline \multirow{6}{*}{3} & \multirow{6}{*}{$\begin{array}{l}\text { High Fluoride } \\
\text { Affected Locale }\end{array}$} & \multirow{6}{*}{ Erode } & \multirow{3}{*}{ Athani } & 1 & \multirow{3}{*}{15} \\
\hline & & & & 2 & \\
\hline & & & & 3 & \\
\hline & & & \multirow{3}{*}{ Ammapettai } & 1 & \multirow{3}{*}{15} \\
\hline & & & & 2 & \\
\hline & & & & 3 & \\
\hline \multicolumn{4}{|l|}{ Sub Total (C) } & 6 & 30 \\
\hline 4 & $\begin{array}{l}\text { Non Affected } \\
\text { Locale }\end{array}$ & Coimbatore & & 3 & \\
\hline Sub Total (D) & & & & 6 & 30 \\
\hline Grand Total ( & $C+D)$ & & & 24 & 120 \\
\hline
\end{tabular}

